\title{
Arsenic in groundwater and sediments from La Pampa Province, Argentina
}

\author{
P. L. Smedley \\ British Geological Survey, Maclean Building, Wallingford, Oxfordshire, OX10 8BB, UK
}

H. B. Nicolli

Instituto de Geoquímica, Av. Mitre 3100, 1663 San Miguel, Provincia de Buenos Aires, Argentina

D. M. J. Macdonald

British Geological Survey, Maclean Building, Wallingford, Oxfordshire, OX10 8BB, UK

D. G. Kinniburgh

British Geological Survey, Maclean Building, Wallingford, Oxfordshire, OX10 8BB, UK

\begin{abstract}
Arsenic in pumped groundwaters from the Quaternary loess aquifer of northern La Pampa, Argentina, has concentrations in the range $<4-5300 \mu \mathrm{g} / \mathrm{L}$, most being present as the oxidised arsenate form. Other anions and oxyanions (B, F, Mo, V, U) also often have high concentrations. These trace elements show positive correlations with both $\mathrm{pH}$ and alkalinity. Arsenic concentrations are particularly high in pumped groundwaters and porewaters beneath small topographic depressions which act as zones of seasonal discharge and restricted groundwater flow. Evaporation of water in these small internal drainage systems can be significant but is not responsible for the observed high As concentrations. Accumulation of As (dissolved and sorbed) through flow towards the depression and lack of flushing are likely controls. The As may be derived from a number of minerals but sorption/desorption reactions involving Fe oxides and possibly Mn oxides are considered important controls on the mobility of As, sorption being weakest at high $\mathrm{pH}$. Modelling suggests that competition from other anions, especially vanadate, for binding sites on Fe oxides can further enhance the concentrations of As in the groundwater.
\end{abstract}

\section{INTRODUCTION}

The Chaco-Pampean plain of Argentina represents one of the largest identified high-As groundwater provinces in the world, extending over an area of around 1 million $\mathrm{km}^{2}$. Several studies over the last few years have highlighted problems with high groundwater As concentrations in the region (Bundschuh et al., 2004; Farias et al., 2003; Nicolli et al., 1989; Nicolli et al., 2001; Nicolli et al., 2000; Nicolli et al., 2004; Uriarte et al., 2002; Warren, 2001). In a number of cases, documented average groundwater As concentrations are in excess of $100 \mu \mathrm{g} / \mathrm{L}$, several samples containing in excess of $1000 \mu \mathrm{g} / \mathrm{L}$ (Table 1). The concentrations are among the highest observed in low-temperature natural groundwaters. As large areas of Argentina are semi-arid, surface water resources are scarce and hence groundwater is an important resource for both public and private supply.

Table 1. Summary statistical data for As $(\mu \mathrm{g} / \mathrm{L})$ in groundwater from the Chaco-Pampean Plain.

\begin{tabular}{lcccrll}
\hline Province (Argentina) & Min & Median & Mean & \multicolumn{1}{c}{ Max } & n & Reference \\
\hline Córdoba & 18.7 & 255 & 418 & 3810 & 60 & Nicolli et al. (1989) \\
Tucumán, Los Pereyra (shallow) & 19.7 & 185 & 272 & 758 & 31 & Warren (2001) \\
Tucumán, Los Pereyra (deep) & 0.25 & 5.9 & 12 & 70 & 25 & Warren (2001) \\
Tucumán, Salí River (shallow) & 12.2 & 45.8 & 159 & 1660 & 42 & Nicolli et al. (2000; 2004) \\
Tucumán, Salí River (deep) & 11.4 & 33.7 & 37.9 & 107 & 26 & Nicolli et al. (2000; 2004) \\
Córdoba/B. Aires/Santa Fe/San Luis & 10 & 67 & 108 & 593 & 66 & Farias et al. (2003) \\
Santiago del Estero (1998) & 2 & - & 170 & 2400 & 65 & Bundschuh et al. (2004) \\
La Pampa & $<4$ & 150 & 414 & 5300 & 108 & Smedley et al. (2002) \\
\hline
\end{tabular}



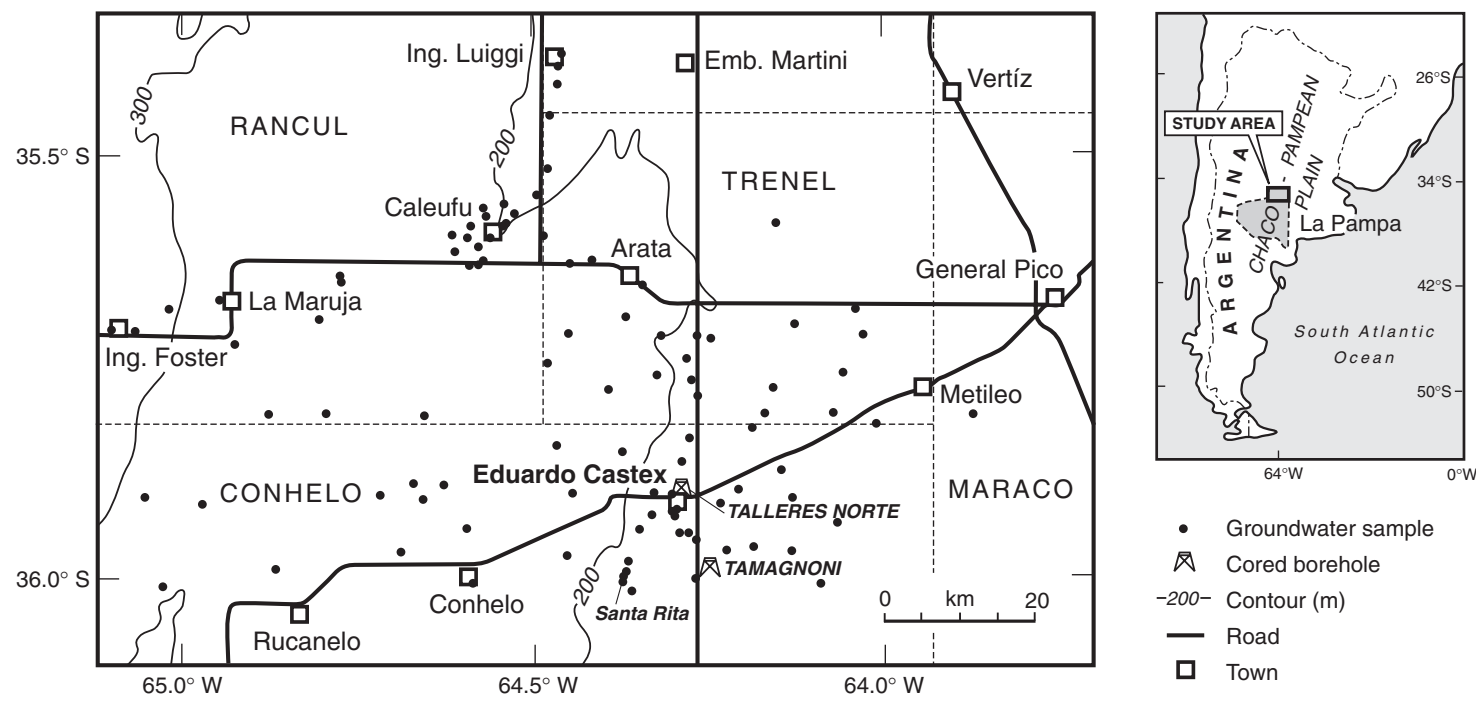

- Groundwater sample

冈 Cored borehole

-200- Contour (m)

- Road

ㅁown

Figure 1. Map of northern La Pampa Province, showing groundwater sampling locations and locations of cored boreholes (Talleres Norte and Tamagnoni) (from Smedley et al., 2002).

Health problems linked to chronic exposure to As from drinking water have been documented in the region since the early 20th century. These include the condition locally known as Bell Ville disease, a skin disorder manifested by pigmentation changes and keratosis, first documented in the town of Bell Ville in Córdoba Province. Recognised health problems also include skin, bladder and lung cancer (Bates et al., 2003; Bates et al., 2004; Cabrera \& Gómez, 2003; Hopenhayn-Rich et al., 1996).

The affected groundwaters are present in Quaternary loess deposits, occasionally reworked by fluvial processes. These form a superficial cover over the Chaco-Pampean Plain, in places reaching several hundreds of metres thick. The loess deposits are dominantly silts and often contain a significant component of intermixed volcanic glass shards. Occasional discrete volcanic ash horizons also occur. The loess sediments typically have silica and alkali contents comparable to dacite and the ash deposits are rhyolitic. Calcretes are also well-developed, occurring throughout the sedimentary sequence as components of the matrix or as nodules, veins or extensive sheets. These, together with palaeosols, have developed during the Quaternary history of the region under the semi-arid climatic conditions (Zárate \& Fasano, 1989).

This paper summarises the results of hydrogeochemical investigations of groundwaters, sediments and sediment extracts carried out in the northern part of the province of La Pampa (Fig. 1). The study area consists of a gently undulating plain with a slight easterly slope of around 0.0014 . The area covers $110 \times 70 \mathrm{~km}$ and is dominantly rural but includes several towns, the largest of which is Eduardo Castex. The Quaternary loess aquifer is the only source of water supply in the area and the groundwater generally occurs under unconfined conditions.

\section{GROUNDWATER CHEMISTRY}

Groundwater chemistry investigations in the study area have been described by Smedley et al. (2002). Pumped groundwater samples have been collected from 108 existing wells and boreholes which vary in depth from $6-140 \mathrm{~m}$. The groundwaters are mainly of $\mathrm{Na}-\mathrm{HCO}_{3}$ or Namixed-anion type, although salinity is often high under the ambient semi-arid conditions, and some more saline samples are of $\mathrm{Na}-\mathrm{Cl}$ composition. Total-dissolved-solids concentrations have a large range from $730-11,500 \mathrm{mg} / \mathrm{L}$ (Smedley et al., 2002). Groundwater $\mathrm{pH}$ values are neutral to alkaline (7.0-8.7 in pumped groundwater) and alkalinity is often high $\left(\mathrm{HCO}_{3}{ }^{195}-\right.$ $1440 \mathrm{mg} / \mathrm{L}$; Fig. 2), resulting largely from silicate hydrolysis reactions. The groundwaters are also overwhelmingly oxic, with detectable dissolved oxygen, often high nitrate concentrations $\left(\mathrm{NO}_{3}-\mathrm{N}<0.2-140 \mathrm{mg} / \mathrm{L}\right)$ and low concentrations of dissolved $\mathrm{Fe}$ and $\mathrm{Mn}$. 


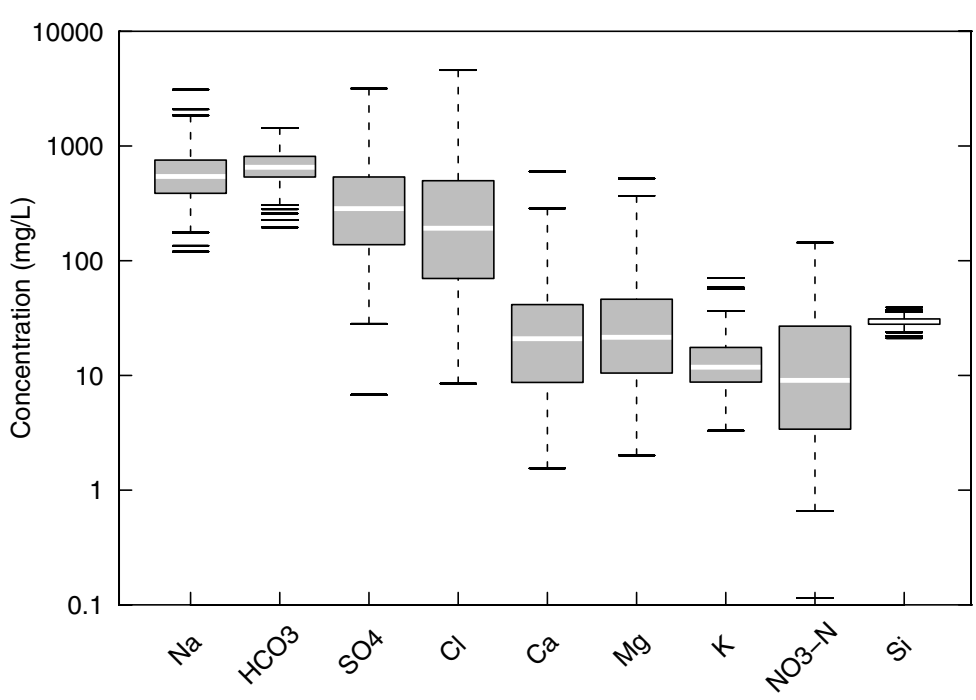

Trace elements

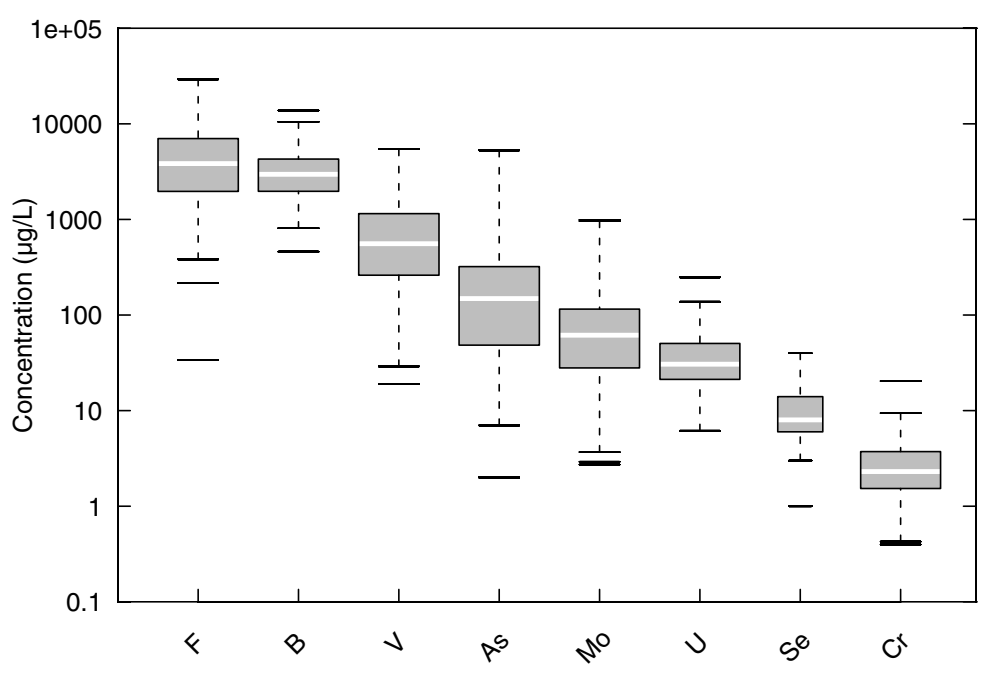

Figure 2. Box plots of selected major ions and trace elements in the groundwaters of northern La Pampa. Boxes represent the interquartile range, whiskers are 1.5 times the interquartile range and white horizontal lines are the median values. 'Outliers' are shown as isolated horizontal lines. Box widths are proportional to the square root of the numbers of samples.

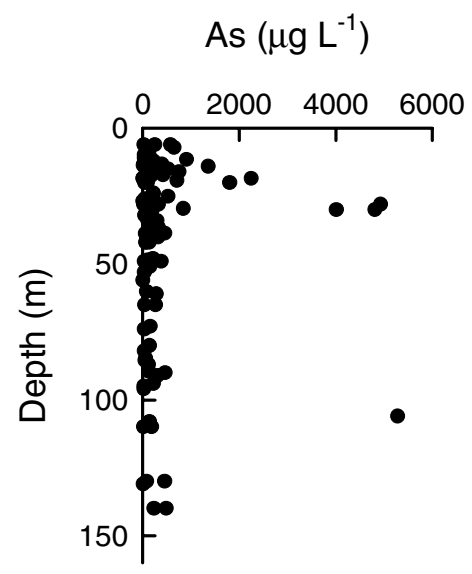

Figure. 3. Arsenic variation with borehole or well depth in the pumped groundwaters of the study area. 
Arsenic concentrations in the 108 pumped groundwater samples lie in the range $<4$ $5300 \mu \mathrm{g} / \mathrm{L}$ (median $150 \mu \mathrm{g} / \mathrm{L}$; Table 1; Fig. 2). 95\% of these samples have concentrations exceeding the WHO guideline value for As in drinking water of $10 \mu \mathrm{g} / \mathrm{L} ; 73 \%$ exceed the Argentine national standard of $50 \mu \mathrm{g} / \mathrm{L}$. Arsenic is dominantly present in solution as the oxidized form, $\mathrm{As}(\mathrm{V})$ (Smedley et al., 2002). Most of the groundwaters with concentrations of As greater than $1000 \mu \mathrm{g} / \mathrm{L}$ are from wells or boreholes with depths less than $40 \mathrm{~m}$ (Fig. 3).

A number of other solutes which form anions and oxyanions in oxic alkaline conditions also have high concentrations in the Pampean groundwaters. These include $\mathrm{B}, \mathrm{F}, \mathrm{Mo}, \mathrm{V}$ and $\mathrm{U}$, which reach up to $13.8 \mathrm{mg} / \mathrm{L}, 29.2 \mathrm{mg} / \mathrm{L}, 990 \mu \mathrm{g} / \mathrm{L}, 5.4 \mathrm{mg} / \mathrm{L}$ and $250 \mu \mathrm{g} / \mathrm{L}$ respectively (Fig. 2). Although fewer samples were analysed for Se, concentrations are also often high, reaching up to $40 \mu \mathrm{g} / \mathrm{L}$.
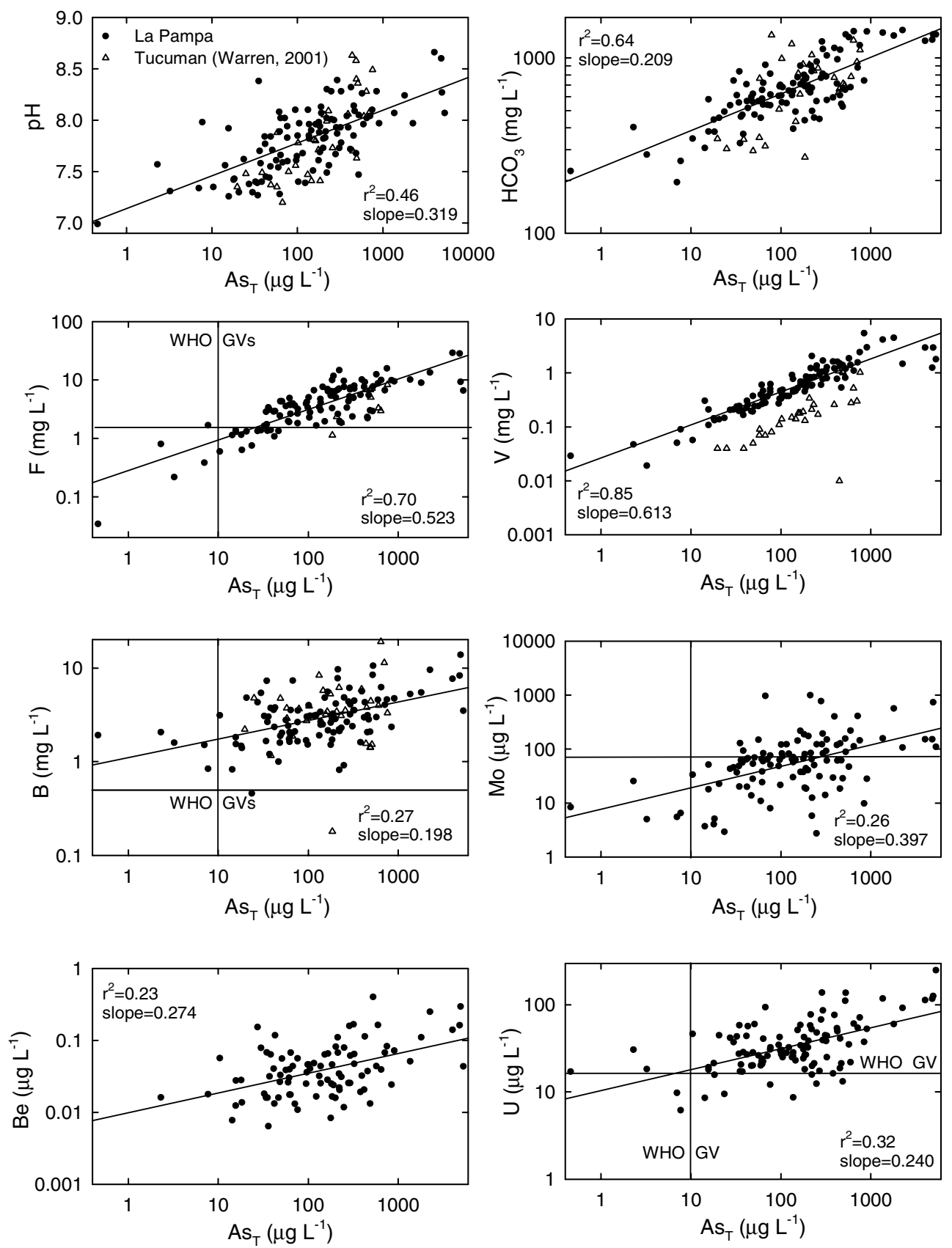

Figure 4. Variation of As with other anion and oxyanion-forming species in groundwaters from La Pampa (after Smedley et al., 2002) and Tucumán (Warren, 2001). Trace-element concentrations have not been left-censored. Correlation coefficients refer to La Pampa data only. Where applicable, WHO guideline values (GVs) are also given (WHO, 2004). 
Positive correlations are apparent between As and both $\mathrm{pH}$ and alkalinity $\left(\mathrm{HCO}_{3}\right.$; Fig. 4). Good positive correlations are also found with $\mathrm{F}$ and $\mathrm{V}$, as well as weaker correlations with a number of other anion- and oxyanion-forming elements (Fig. 4). In contrast, Se does not correlate with As, concentrations indicating instead a broad positive correlation with salinity. The correlation with dissolved $\mathrm{P}$ is also poor.

Associations in alkaline, oxidising groundwaters between many dissolved anions and oxyanion species have been reported by a number of workers from elsewhere in Argentina (Nicolli et al., 1989; Nicolli et al., 2001; Nicolli et al., 2004; Warren, 2001) and the USA (Robertson, 1989). Warren (2001) described the chemistry of groundwater in the analogous Quaternary loess aquifer of Los Pereyras area, Tucumán. Data for groundwaters from the Tucumán shallow aquifer (borehole depths $<40 \mathrm{~m}$ ) are plotted alongside those from La Pampa in Figure 4 . The dataset shows comparable concentration ranges for $\mathrm{pH}, \mathrm{HCO}_{3}, \mathrm{~F}$ and $\mathrm{B}$, although the highest concentrations of As (up to $758 \mu \mathrm{g} / \mathrm{L}$ ) are less extreme than those found in La Pampa. The correlation between As and V is equally strong in the Tucumán samples, although V concentrations are consistently lower. The similarities between the data from the two regions point to similar aquifer conditions and geochemical processes. Differences in $\mathrm{V}$ concentration ranges most likely relate to variations in source mineralogy.

Porewaters extracted by centrifugation from two cored boreholes, named as Talleres Norte and Tamagnoni (Fig. 1), also show broad positive correlations between As and $\mathrm{pH}, \mathrm{HCO}_{3}, \mathrm{~B}, \mathrm{~F}$, $\mathrm{V}$ and U (Fig. 5), although concentrations of some diminish at extremely high As concentrations. The absolute concentrations of the oxyanions can vary significantly between the two sites. The boreholes were drilled to $26.5 \mathrm{~m}$ and $30 \mathrm{~m}$ respectively, Talleres Norte located in a flatlying area in Eduardo Castex and likely to be a recharge area, Tamagnoni on the edge of a small topographic depression, $10 \mathrm{~km}$ to the south. This depression has been water-filled over the last few years although water levels fluctuate as a result of seasonal evaporation. Like many other topographic depressions in the region, it is likely to be a zone of seasonal groundwater discharge resulting in local upward flow. Porewaters from the Tamagnoni borehole reveal very high $\mathrm{Cl}$ concentrations in the topmost $5 \mathrm{~m}$ or so of the saturated aquifer as a result of evaporative concentration in the shallow subsurface (although they are strongly undersaturated with halite and not likely to have derived $\mathrm{Cl}$ from dissolution of this mineral). Chloride concentrations fall to around $100 \mathrm{mg} / \mathrm{L}$ or less at depths greater than $10 \mathrm{~m}$ below surface (Fig. 6).
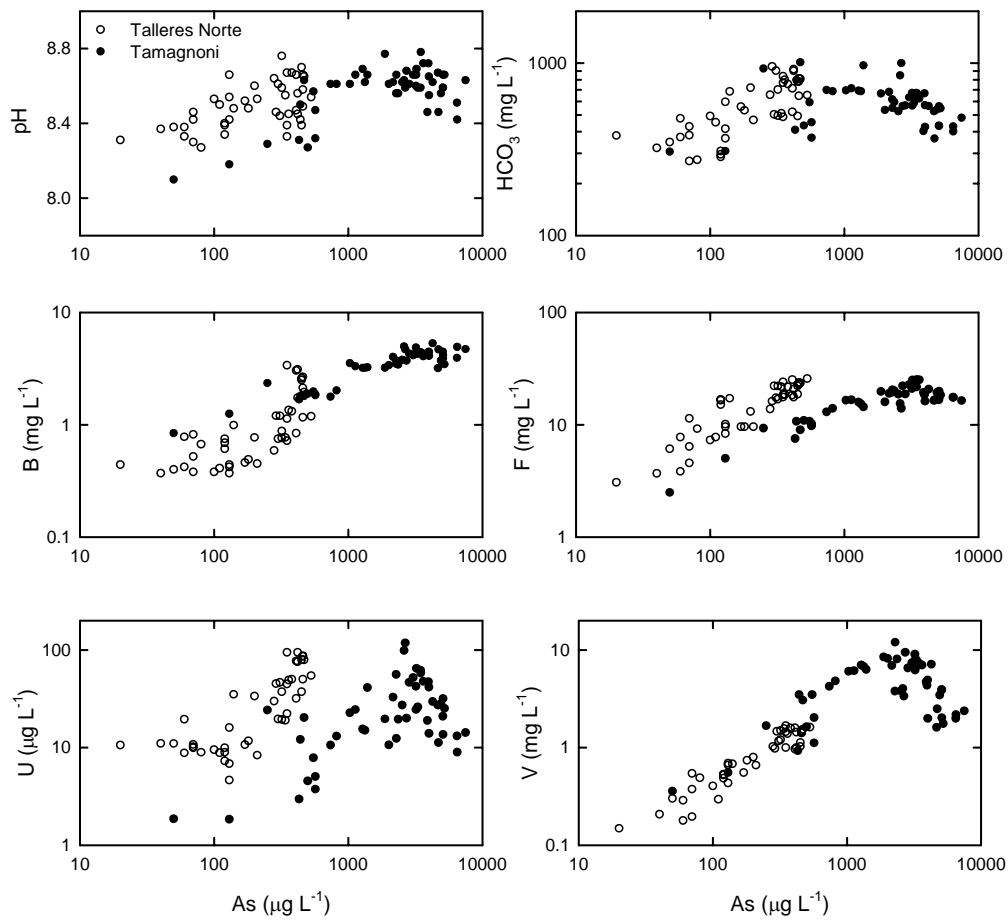

Figure 5. Variation of As with some other anion and oxyanion-forming species in porewaters from two cored boreholes (Talleres Norte and Tamagnoni) in the study area. 


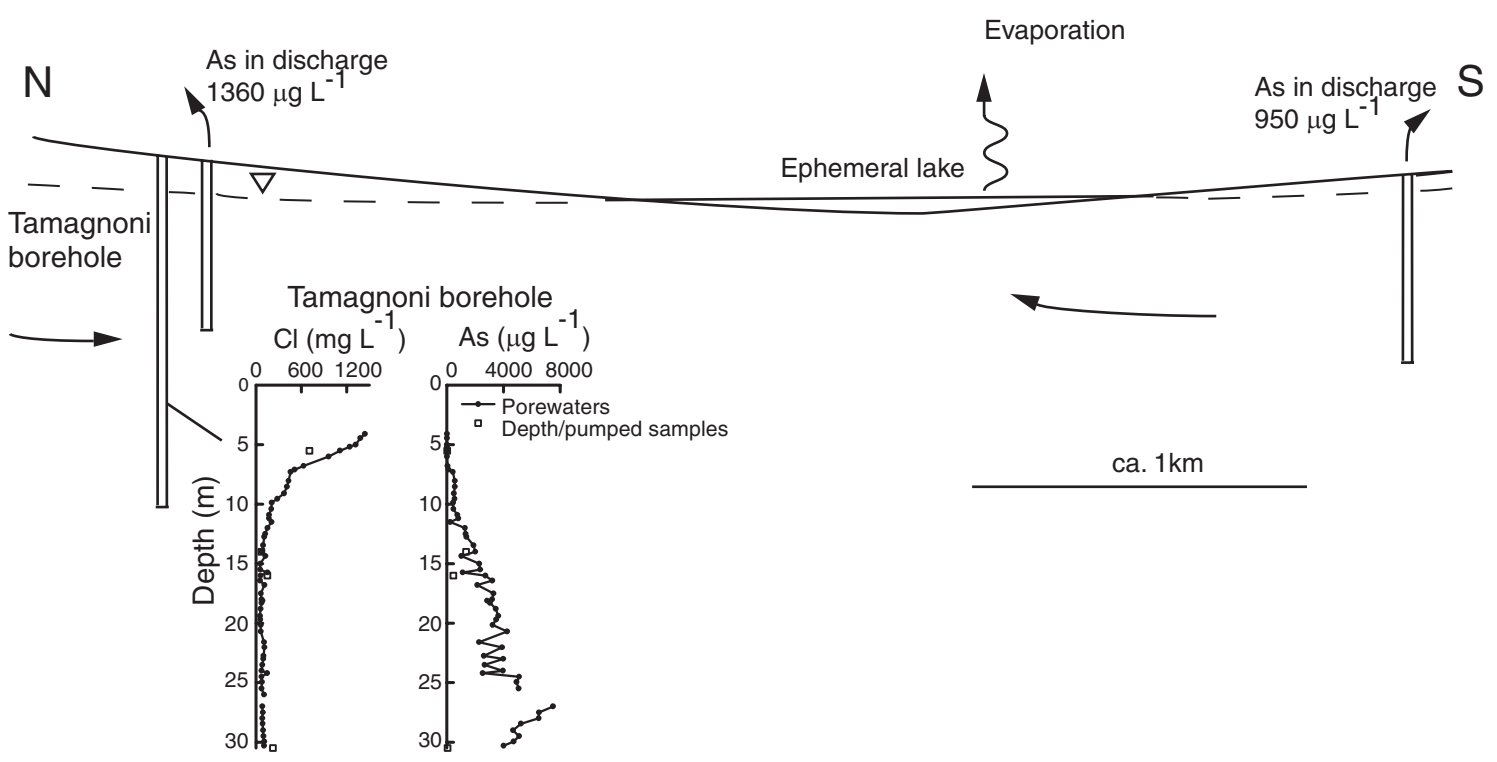

Figure 6. Sketch cross section of a topographic depression in the southern part of the study area, showing As concentrations in samples from abstraction boreholes and porewater profiles for $\mathrm{Cl}$ and As in the

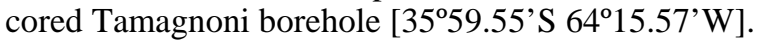

In contrast, As concentrations show an overall increase with depth in the porewaters from the Tamagnoni borehole (Fig. 6). This cannot be related to simple evaporative concentration because of the inverse relationship with $\mathrm{Cl}$. The concentrations of As (and other oxyanions) increase in higher-pH Na- $\mathrm{HCO}_{3}$ groundwaters at greater depth in the porewaters. Arsenic concentrations in the Tamagnoni porewaters reach up to $7500 \mu \mathrm{g} / \mathrm{L}$, an order of magnitude higher than is found in the porewaters of Talleres Norte (up to $530 \mu \mathrm{g} / \mathrm{L}$ ). Concentrations of V are also an order of magnitude higher in the Tamagnoni porewaters. These much higher oxyanion accumulations in the topographic low area are believed to be the result of groundwater flow directions (upwards towards the depression) resulting in an accumulation of solutes locally due to poor flushing and increased residence time.

The alkaline, high-As and associated high-oxyanion groundwaters found in La Pampa appear to be a feature largely specific to the shallow Quaternary loess aquifers of Argentina. Warren (2001) found that deeper groundwaters $(>70 \mathrm{~m})$ in a Tertiary aquifer in Tucumán Province had generally much lower concentrations of As (up to $70 \mu \mathrm{g} / \mathrm{L}$ ) and V (up to $130 \mu \mathrm{g} / \mathrm{L}$ ). Nicolli et al. (2001) also found much lower concentrations of As and V in deep groundwaters from a Tertiary aquifer in the Salí River Basin of Tucumán. Arsenic concentrations were 11.4-107 $\mu \mathrm{g} / \mathrm{L}$ and $\mathrm{V}$ were $48-113 \mu \mathrm{g} / \mathrm{L}$ which, although sometimes high, were less extreme than those seen in the overlying shallow Quaternary aquifer (As 12.2-1660 $\mu \mathrm{g} / \mathrm{L} ; \mathrm{V} \mathrm{30.7-300} \mathrm{\mu g/L).} \mathrm{Nicolli} \mathrm{et} \mathrm{al.}$ (2001) also found relatively low concentrations in deep groundwaters from the Burruyacú Basin of Tucumán (As of 13.8-37 $\mu \mathrm{g} / \mathrm{L}$; $\mathrm{V}$ of 13.3-61 $\mu \mathrm{g} / \mathrm{L}$ ), compared to those in the shallow aquifer above (As of 15.8-1610 $\mu \mathrm{g} / \mathrm{L}$; V of 17-1090 $\mu \mathrm{g} / \mathrm{L}$ ).

These distinct groundwater compositions with depth imply significant differences in sediment chemistry and/or groundwater flow in the different aquifers. Controlling factors could include stratigraphic variations in mineralogy, content of volcanic ash and amount of groundwater flushing since sediment deposition. Determination of the relative significance of these processes is difficult without more information on the mineralogy, geochemistry and groundwater flow in these deeper aquifers.

\section{SEDIMENT CHEMISTRY}

Investigations of the chemistry of sediments in the loess aquifer of La Pampa have been described by Smedley et al. (2005). Some of the salient features are summarised here. 
Table 1. Summary statistical data for samples of loess sediment (including rhyolitic ash samples) from the study area (major oxides, LOI and TOC in weight \%, trace elements in mg/kg).

\begin{tabular}{llllllllll}
\hline Parameter & Min & Median Max & $\mathrm{n}$ & Parameter Min & Median & Max & $\mathrm{n}$ \\
\hline $\mathrm{SiO}_{2}$ & 39.25 & 61.69 & 69.41 & 50 & $\mathrm{As}$ & 3 & 7 & 18 & 50 \\
$\mathrm{TiO}_{2}$ & 0.37 & 0.71 & 0.85 & 50 & $\mathrm{Ba}$ & 276 & 529 & 1430 & 50 \\
$\mathrm{Al}_{2} \mathrm{O}_{3}$ & 10.18 & 15.14 & 16.72 & 50 & $\mathrm{Cd}$ & $<1$ & $<1$ & 2 & 36 \\
$\mathrm{Fe}_{2} \mathrm{O}_{3 \mathrm{~T}}$ & 2.1 & 4.83 & 5.97 & 50 & $\mathrm{Co}$ & 5 & 12.5 & 19 & 50 \\
$\mathrm{Mn}_{3} \mathrm{O}_{4}$ & 0.06 & 0.095 & 0.15 & 50 & $\mathrm{Cr}$ & $<2$ & 23.5 & 33 & 48 \\
$\mathrm{MgO}$ & 0.48 & 1.86 & 2.8 & 50 & $\mathrm{Cu}$ & 6 & 26 & 36 & 50 \\
$\mathrm{CaO}$ & 1.51 & 3.35 & 21.97 & 50 & $\mathrm{~F}$ & $<500$ & $<500$ & 984 & 50 \\
$\mathrm{Na}_{2} \mathrm{O}$ & 1.68 & 2.69 & 4.79 & 50 & $\mathrm{Mo}$ & $<1$ & $<1$ & 6 & 50 \\
$\mathrm{~K}_{2} \mathrm{O}$ & 1.32 & 2.36 & 4.04 & 50 & $\mathrm{Ni}$ & $<1$ & 12 & 18.5 & 50 \\
$\mathrm{P}_{2} \mathrm{O}_{5}$ & 0.08 & 0.15 & 0.24 & 50 & $\mathrm{Rb}$ & 38 & 80 & 118 & 50 \\
$\mathrm{ZrO}$ & 0.02 & 0.02 & 0.04 & 34 & $\mathrm{Sb}$ & $<1$ & $<1$ & 1 & 50 \\
$\mathrm{BaO}$ & 0.04 & 0.07 & 0.18 & 34 & $\mathrm{Se}$ & $<1$ & $<1$ & 1 & 50 \\
$\mathrm{LOI}$ & 1.83 & 4.79 & 18.28 & 50 & $\mathrm{Sr}$ & 142 & 335 & 752 & 50 \\
$\mathrm{TOC}$ & 0.02 & 0.08 & 0.94 & 41 & $\mathrm{Th}$ & 5 & 7.6 & 12 & 36 \\
& & & & & $\mathrm{U}$ & 0.9 & 2.5 & 5.1 & 50 \\
& & & & & $\mathrm{~V}$ & 22 & 90 & 174 & 36 \\
& & & & & $\mathrm{Zn}$ & 36 & 56 & 105 & 50
\end{tabular}

The loess sediments contain abundant plagioclase, with variable amounts of quartz, alkali feldspar, altered ferromagnesian minerals and heavy minerals (especially ilmenite and magnetite) within a smectite-illite clay matrix. Volcanic glass is abundant in some samples, as are secondary Mn oxides.

Summary statistics for up to 50 sediment samples from the study area (including 5 samples of rhyolitic ash) are given in Table 1 . The silicic nature of most of the loess silts reflects the composition of the Andean volcanic rocks from which they are dominantly derived.

Concentrations of total As in the sediments lie in the range $3-18 \mathrm{mg} / \mathrm{kg}$ (median $7 \mathrm{mg} / \mathrm{kg}$ ). These are broadly comparable with the concentrations of As found in average sediments, which are typically around 5-10 mg/kg (Smedley \& Kinniburgh, 2002). Vanadium concentrations in the Pampean sediments are in the range $22-174 \mathrm{mg} / \mathrm{kg}$ (median $90 \mathrm{mg} / \mathrm{kg}$ ), lowest concentrations being from the rhyolitic ashes. These compare to concentrations of 39-99 mg/kg in loess deposits from other parts of the world and an estimated average upper crustal V concentration of $60 \mathrm{mg} / \mathrm{kg}$ (Taylor et al., 1983). Likewise, Taylor et al. (1983) found U concentrations of 1.8$3.0 \mathrm{mg} / \mathrm{kg}$ in loess deposits elsewhere and quoted an average upper crustal $\mathrm{U}$ concentration of $2.5 \mathrm{mg} / \mathrm{kg}$. These values compare to $\mathrm{U}$ concentrations of $0.9-5.1 \mathrm{mg} / \mathrm{kg}$ (median value $2.5 \mathrm{mg} / \mathrm{kg}$ ) in the Pampean loess samples. The concentrations of these oxyanion-forming elements are therefore at the high end of the ranges of concentrations found in loess and other sediments elsewhere, but do not appear to be exceptional.

\section{CONTROLS ON ARSENIC MOBILITY}

The sources of As in the sediments are difficult to define because only very small amounts of the element need to be released from the solid phase to produce the concentrations of dissolved As observed in the groundwaters. Hence, many minerals may be potential candidates, including silicates (volcanic glass, pyroxene, amphibole, biotite, clays) and oxides (magnetite, ilmenite or secondary $\mathrm{Fe}, \mathrm{Al}$ and $\mathrm{Mn}$ oxides). Sulphide minerals are rare and not considered significant. The volcanic components of the loess deposits are likely to be important primary sources of As and other oxyanions. These are fine-grained, recently erupted and unstable in the weathering environment. The As associated with them may therefore be in a relatively labile form. However, the sediments also contain abundant $\mathrm{Fe}, \mathrm{Mn}$ and $\mathrm{Al}$ oxides which are known to play an important role in the cycling of As between the solid and dissolved phase. The metal oxides are therefore likely to be a significant control on the As concentrations in the groundwaters. 


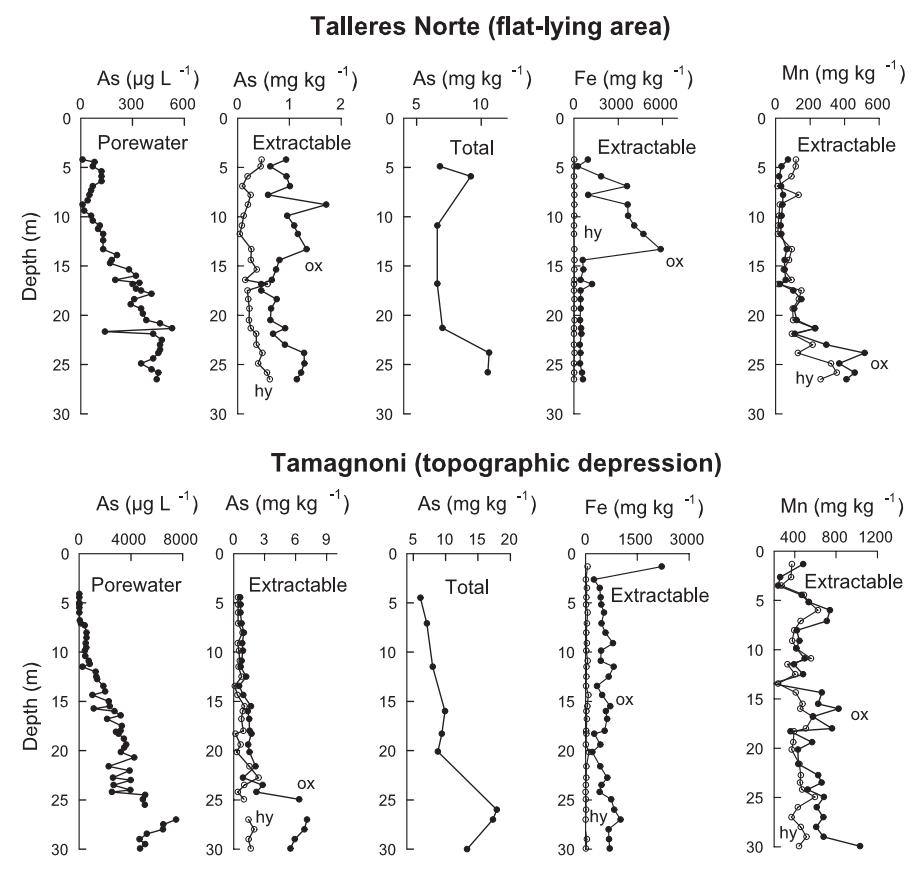

Figure 7. Porewater, sediment and sediment extract (oxalate- (ox) and hydroxylamine- (hy) extractable) profiles for As, Fe and Mn in the Talleres Norte and Tamagnoni boreholes (after Smedley et al., 2005).

Although the sediments do not appear to have extremely high As concentrations when compared to sediments elsewhere, profiles from the two cored boreholes at Talleres Norte and Tamagnoni show some notable correlations between porewater As concentrations and total sediment As concentrations (Fig. 7).

Correlations are also apparent between porewater As and both oxalate-extractable and hydroxylamine-extractable As concentrations, measured to assess the contribution of As from amorphous or poorly-structured Fe oxides and Mn oxides respectively. The highest observed total and extractable As concentrations are found in the deepest part of the Tamagnoni borehole, where the porewaters contain up to $7500 \mu \mathrm{g} / \mathrm{L}$ As. Here, up to $50 \%$ of the As appears to be oxalate-extractable (Fig. 7) and is therefore relatively labile.

Relationships with extractable Fe and Mn concentrations are less clear, but there appears some correlation at least in the Talleres Norte profile with $\mathrm{Fe}_{\mathrm{ox}}$ at shallow depths and $\mathrm{Mn}_{\mathrm{ox}}$ at greater depth. This suggests that As is associated at least in part with poorly-structured Fe and Mn oxides. No correlation was found between dissolved $\mathrm{As}$ and $\mathrm{Al}_{\mathrm{ox}}$, although a control by $\mathrm{Al}$ oxide cannot be discounted. Magnetite can potentially be extracted in oxalate solutions and the $\mathrm{Fe}_{\mathrm{ox}}-\mathrm{As}_{\mathrm{ox}}$ relationships between mean that magnetite may be an additional source and sink of As. As the sediments and groundwaters of the area are overwhelmingly oxic, controls on As mobility by these oxides must be achieved by sorption/desorption reactions involving dominantly arsenate $(\mathrm{As}(\mathrm{V}))$. The $\mathrm{pH}$-dependence of arsenate sorption on $\mathrm{Fe}$ and $\mathrm{Al}$ oxides is wellknown (e.g. Dixit \& Hering, 2003; Goldberg \& Johnston, 2001; Rietra et al., 1999). Binding of arsenate to these metal oxides should therefore be at its weakest in the high-pH waters.

Exploratory modelling using the diffuse double-layer model and the Dzombak and Morel (1990) default database for hydrous ferric oxide (HFO) in PHREEQC (Parkhurst \& Appelo, 1999) indicates that competitive effects from other anionic solutes may also have a significant impact on dissolved As concentrations. Smedley et al. (2005) modelled the sorption of As by a $1 \mathrm{~g} / \mathrm{L}$ suspension of HFO by equilibrating with solutions having the chemistry of the porewaters in the Talleres Norte and Tamagnoni boreholes. Modelling was carried out by inclusion of As alone and then by inclusion of potentially competing anions. The models suggested that the log $K_{\mathrm{d}}$ values (ratio of sorbed to solution As) were up to an order of magnitude lower when the competitors (especially V and P) were included compared to when As was considered as the only sorbing anion. This suggests that high concentrations of elements such as $\mathrm{V}$ can have a strong competitive effect and can further enhance As mobility. A more detailed analysis requires better models and databases (Rietra et al., 1999). 


\section{CONCLUSIONS}

Groundwater from the Quaternary loess aquifer of northern La Pampa has spatially variable but often high concentrations of As. Pumped groundwater samples from boreholes and wells have an observed range of $<4-5300 \mu \mathrm{g} / \mathrm{L}$. The dissolved As correlates positively with several other trace elements which also reach unusually high concentrations, $\mathrm{V}$ concentrations reaching up to $5.4 \mathrm{mg} / \mathrm{L}$, F up to $29 \mathrm{mg} / \mathrm{L}$, B up to $14 \mathrm{mg} / \mathrm{L}$, Mo up to $990 \mu \mathrm{g} / \mathrm{L}$ and $\mathrm{U}$ up to $250 \mu \mathrm{g} / \mathrm{L}$. The groundwater is universally oxic with a neutral to alkaline $\mathrm{pH}(7.0-8.7)$ and the dissolved As is present predominantly as $\mathrm{As}(\mathrm{V})$. Highest concentrations of these anion and oxyanion species tend to be present in the high-pH, $\mathrm{Na}-\mathrm{HCO}_{3}$ groundwaters.

The mineral sources of the As in the groundwater are difficult to identify unequivocally. The aquifer sediments have unremarkable concentrations of As (3-18 mg/kg) although porewater As concentrations correlate broadly with host sediment As concentrations. The sediment As data indicate that weak binding of As to the sediments rather than exceptionally high As concentrations in the source are responsible for the high groundwater As concentrations observed. Oxalate and hydroxylamine sediment extracts from cored boreholes show some association between As and either $\mathrm{Fe}$ or $\mathrm{Mn}$ oxides in different parts of the profiles and suggest that sorption/desorption reactions involving these minerals may be important in controlling As mobility. The evidence for an association with $\mathrm{Al}$ oxides is less clear but these may also be involved.

Some of the highest concentrations of As and associated trace-elements are found beneath topographic depressions. Porewater from a cored borehole in one investigated topographic depression (Tamagnoni borehole) had As concentrations up to $7500 \mu \mathrm{g} / \mathrm{L}$. The depressions are likely to be zones of periodic groundwater discharge and increased residence time. This increased residence time is believed an important factor controlling the accumulation of such high concentrations of As and other oxyanions.

Modelling of As sorption to HFO suggests that competition from other anions can have a significant effect on the amounts of sorbed As, the biggest effect being from vanadate at the concentrations of solutes observed. Although hydrous ferric oxide is probably not the dominant Fe(III) oxide present in the Pampean aquifer, it serves as a useful indicator of the likely reactions involved in As release to groundwater in the region.

As permanent surface-water courses are absent in La Pampa, groundwater is the only available source of water for public and private supply. Options for mitigation are therefore very limited. Water treatment (reverse osmosis) is carried in many urban areas in the region. This is effective but expensive and currently less used in domestic settings. Abstraction from deeper boreholes may offer some benefits in terms of water quality as our data suggest that the groundwaters with the most extreme As concentrations (greater than $1000 \mu \mathrm{g} / \mathrm{L}$ ) are generally found in boreholes or wells of less than $40 \mathrm{~m}$ depth. However, since $95 \%$ of the groundwaters sampled have As concentrations above the WHO guideline value for drinking water, with $73 \%$ above the Argentine national As standard, drilling deeper wells within the loess deposits is still unlikely to provide groundwater with acceptably low As concentrations. Groundwaters from deeper pre-Quaternary aquifers in other parts of the Chaco-Pampean Plain have been found to contain lower concentrations of As and associated anionic species, often below drinking-water limits. These offer some potential as alternative sources of water where they occur, but their capital cost implications as well as long-term viability and lateral extent across the ChacoPampean Plain need to be assessed more thoroughly.

\section{REFERENCES}

Bates, M.N., Rey, O., Biggs, M.L., Hopenhayn, C., Moore, L.F., Kalman, D., Steinmaus, C. \& Smith, A. 2003. Arsenic in drinking water and bladder cancer in Argentina: Results of a case-control study. Epidemiology 14(5): S123-S123.

Bates, M.N., Rey, O.A., Biggs, M.L., Hopenhayn, C., Moore, L.E., Kalman, D., Steinmaus, C. \& Smith, A.H. 2004. Case-control study of bladder cancer and exposure to arsenic in Argentina. American Journal of Epidemiology 159(4): 381-389. 
Bundschuh, J., Farias, B., Martin, R., Storniolo, A., Bhattacharya, P., Cortes, J., Bonorino, G. \& Albouy, R. 2004. Groundwater arsenic in the Chaco-Pampean Plain, Argentina: Case study from Robles County, Santiago del Estero Province. Applied Geochemistry 19(2): 231-243.

Cabrera, H.N. \& Gómez, M.L. 2003. Skin cancer induced by arsenic in the water. Journal of Cutaneous Medicine and Surgery 7(2): 106-111.

Dixit, S. \& Hering, J.G. 2003. Comparison of arsenic(V) and arsenic(III) sorption onto iron oxide minerals: Implications for arsenic mobility. Environmental Science \& Technology 37(18): 4182-4189.

Dzombak, D.A. \& Morel, F.M.M. 1990. Surface Complexation Modelling - Hydrous Ferric Oxide. John Wiley \& Sons: New York.

Farias, S.S., Casa, V.A., Vazquez, C., Ferpozzi, L., Pucci, G.N. \& Cohen, I.M. 2003. Natural contamination with arsenic and other trace elements in ground waters of Argentine Pampean Plain. Science of the Total Environment 309(1-3): 187-199.

Goldberg, S. \& Johnston, C.T. 2001. Mechanisms of arsenic adsorption on amorphous oxides evaluated using macroscopic measurements, vibrational spectroscopy, and surface complexation modeling. Journal of Colloid and Interface Science 234(1): 204-216.

Hopenhayn-Rich, C., Biggs, M.L., Fuchs, A., Bergoglio, R., Tello, E.E., Nicolli, H. \& Smith, A.H. 1996. Bladder-cancer mortality associated with arsenic in drinking water in Argentina. Epidemiology 7: 117-124.

Nicolli, H.B., Suriano, J.M., Peral, M.A.G., Ferpozzi, L.H. \& Baleani, O.A. 1989. Groundwater contamination with arsenic and other trace-elements in an area of the Pampa, province of Cordoba, Argentina. Environmental Geology and Water Sciences 14(1): 3-16.

Nicolli, H.B., Tineo, A., García, J., Falcón, C. \& Merino, M. Year. Trace-element quality problems in groundwater from Tucumán, Argentina. Water-Rock Interaction 2001, 2001.993-996.

Nicolli, H.B., Tineo, A. \& García, J.W. 2000. Estudio hidrogeológico y de calidad del agua en la cuenca del Río Salí, Provincia de Tucumán, Revista de Geología Aplicada a la Ingeniería y al Ambiente pp. 82-100 Buenos Aires, Argentina.

Nicolli, H.B., Tineo, A., García, J.W., Falcón, C.M., Merino, M.H., Etchichury, M.C., Alonso, M.S. \& Tofalo, O.R. Year. The role of loess in groundwater pollution at Salí River Basin, Argentina. Water-Rock Interaction 11, 2004.1591-1595.

Parkhurst, D.L. \& Appelo, C.A.J. 1999. User's guide to PHREEQC (Version 2) - A computer program for speciation, batch-reaction, one-dimensional transport, and inverse geochemical calculations. Water-Resources Investigations Report 99-4259(ed.). USGS.

Rietra, R.P.J.J., Hiemstra, T. \& van Riemsdijk, W.H. 1999. The relationship between molecular structure and ion adsorption on variable charge minerals. Geochimica et Cosmochimica Acta 63: 30093015.

Robertson, F.N. 1989. Arsenic in groundwater under oxidizing conditions, south-west United States. Environmental Geochemistry and Health 11(3-4): 171-185.

Smedley, P.L. \& Kinniburgh, D.G. 2002. A review of the source, behaviour and distribution of arsenic in natural waters. Applied Geochemistry 17(5): 517-568.

Smedley, P.L., Kinniburgh, D.G., Macdonald, D.M.J., Nicolli, H.B., Barros, A.J., Tullio, J.O., Pearce, J.M. \& Alonso, M.S. 2005. Arsenic associations in sediments from the loess aquifer of La Pampa, Argentina. Applied Geochemistry 20(5): 989-1016.

Smedley, P.L., Nicolli, H.B., Macdonald, D.M.J., Barros, A.J. \& Tullio, J.O. 2002. Hydrogeochemistry of arsenic and other inorganic constituents in groundwaters from La Pampa, Argentina. Applied Geochemistry 17(3): 259-284.

Taylor, S.R., McLennan, S.M. \& McCulloch, M.T. 1983. Geochemistry of loess, continental crustal composition and crustal model ages. Geochemica et Cosmochimica Acta 47: 1897 - 1905.

Uriarte, M.G., Paoloni, J.D., Navarro, E., Fiorentino, C.E. \& Sequeira, M. 2002. Landscape, surface runoff, and groundwater quality in the district of Puan, Province of Buenos Aires, Argentina. Journal of Soil and Water Conservation 57(3): 192-195.

Warren, C. 2001. Hydrogeology and groundwater quality of Los Pereyras, Tucuman, Argentina. MSc, University College London.

WHO. 2004. Guidelines for Drinking-Water Quality. Volume 1: Recommendations. World Health Organization: Geneva.

Zárate, M.A. \& Fasano, J.L. 1989. The Plio-Pleistocene record of the Central Eastern Pampas, Buenos Aries Province, Argentina - the Chapamalal case-study. Palaeogeography Palaeoclimatology Palaeoecology 72: 27-52. 